\title{
Glomerular Filtration Rate in Former Extreme Low Birth Weight Infants over the Full Pediatric Age Range: A Pooled Analysis
}

\author{
Elise Goetschalckx ${ }^{1}$, Djalila Mekahli ${ }^{1,2}$, Elena Levtchenko ${ }^{1,2}$ and Karel Allegaert ${ }^{1,3,4, *(1)}$ \\ 1 Department of Development and Regeneration, KU Leuven, Herestraat 49, 3000 Leuven, Belgium; \\ elise.goetschalckx@student.kuleuven.be (E.G.); djalila.mekahli@uzleuven.be (D.M.); \\ elena.levtchenko@uzleuven.be (E.L.) \\ 2 Department of Pediatric Nephrology and Organ Transplantation, University Hospitals Leuven, \\ Herestraat 49, 3000 Leuven, Belgium \\ 3 Department of Pharmacy and Pharmaceutical Sciences, KU Leuven, Herestraat 49, 3000 Leuven, Belgium \\ 4 Department of Clinical Pharmacy, Wytemaweg Hospital Pharmacy Postbus 2040, Erasmus MC, Rotterdam, \\ The Netherlands \\ * Correspondence: karel.allegaert@uzleuven.be
}

Received: 8 March 2020; Accepted: 20 March 2020; Published: 24 March 2020

\begin{abstract}
Various cohort studies document a lower glomerular filtration rate (GFR) in former extremely low birth weight (ELBW, $<1000 \mathrm{~g}$ ) neonates throughout childhood when compared to term controls. The current aim is to pool these studies to describe the GFR pattern over the pediatric age range. To do so, we conducted a systematic review on studies reporting on GFR measurements in former ELBW cases while GFR data of healthy age-matched controls included in these studies were co-collected. Based on 248 hits, 6 case-control and 3 cohort studies were identified, with 444 GFR measurements in 380 former ELBW cases (median age 5.3-20.7 years). The majority were small (17-78 cases) single center studies, with heterogeneity in GFR measurement (inulin, cystatin C or creatinine estimated GFR formulae) tools. Despite this, the median GFR ( $\left.\mathrm{mL} / \mathrm{min} / 1.73 \mathrm{~m}^{2}\right)$ within case-control studies was consistently lower $(-13 \%$, range $-8 \%$ to $-25 \%)$ in cases, so that a relevant minority $(15-30 \%)$ has a eGFR $\left.<90 \mathrm{~mL} / \mathrm{min} / 1.73 \mathrm{~m}^{2}\right)$. Consequently, this pooled analysis describes a consistent pattern of reduced eGFR in former ELBW cases throughout childhood. Research should focus on perinatal risk factors for impaired GFR and long-term outcome, but is hampered by single center cohorts, study size and heterogeneity of GFR assessment tools.
\end{abstract}

Keywords: glomerular filtration rate; Brenner hypothesis; extreme low birth weight infants; renal outcome

\section{Introduction}

Due to improvements in perinatal healthcare, the mortality of preterm neonates decreased over the last decades. This decrease applies even more to infants born with an extremely low birth weight (ELBW), i.e., a birth weight $<1000 \mathrm{~g}[1,2]$. However, there is growing evidence that preterm birth in itself is a trait for life as it has consequences on different organ systems, including the renal system. Glomerulogenesis normally finishes at 34-36 weeks of fetal life, but this program is disturbed after preterm birth by preterm birth itself, as well as perinatal events, so that former preterm infants have a decreased radial glomerular count compared to term cases [3,4]. Brenner et al. has put forward the concept ('Brenner hypothesis') that nephron endowment and subsequent single nephron hyperfiltration is a significant factor in the pathogenesis of subsequent chronic kidney disease (CKD) and hypertension [3-5]. As preterm birth disturbs glomerulogenesis and nephron endowment, it is a 
risk factor for CKD and it may be useful to follow up the renal function in former ELBW children, with glomerular filtration rate (GFR) as the most obvious indicator of renal function [3-5].

As we know, GFR can be measured or estimated. GFR measurement by exogenous markers such as inulin, iohexol, mannitol, Cr-EDTA or iothalamate is still the gold standard, but this has its burdens and limitations as screening tool [6,7]. Therefore, GFR is more commonly estimated (eGFR) by endogenous markers like serum creatinine ( $\mathrm{SCr}$ ) or cystatin C (CysC). The SCr-based GFR equation is hereby mostly used, with the CysC-based GFR equations as valid alternatives. The combination of both (SCr-CysC-based GFR equation) has a higher accuracy and precision, also in children [8]. The assessment of eGFR in former ELBW children throughout childhood has reported in observational studies, sometimes compared to age-matched controls. The current aim is to pool these studies to describe the GFR trend over the pediatric age range in former ELBW cases.

\section{Materials and Methods}

This systematic review was conducted along the PRISMA (Preferred Reporting Items for Systematic Reviews and Meta-Analyses) guidelines [9]. To be eligible, participants in the included studies had to be former ELBW newborns, with an age range from infancy until young adulthood and GFR outcome data. Healthy age-matched peers (born term with a normal birth weight) included in these studies as controls were co-enrolled in this analysis to facilitate comparison of GFR between these cases and controls.

The search was performed on March 16th, 2019 without language restriction to retrieve all relevant articles searching Pubmed, Embase, Web of Science and ClinicalTrials.gov respectively [Pubmed: ("infant, extremely low birth weight"[Mesh] OR elbw[tiab] OR extremely-low-birth-weight[tiab] OR extremely-preterm[tiab] OR extremely-low-birthweight[tiab]) AND ("kidney function tests"[Mesh] OR "cystatin C"[Mesh] OR "creatinine"[Mesh] OR "glomerular filtration rate"[Mesh] OR "renal insufficiency, chronic"[Mesh] OR renal-function[tiab] OR renal-complications[tiab] OR renal-follow-up[tiab] OR renal-outcome[tiab] OR kidney-function[tiab]); Embase: ('extremely low birth weight':ti,ab,kw OR 'extremely preterm infant':ti,ab,kw) AND ('kidney function':ti,ab,kw OR 'kidney function test':ti, ab,kw OR 'cystatin c':ti,ab,kw OR 'creatinine':ti,ab,kw OR 'glomerulus filtration rate':ti,ab,kw OR 'kidney failure':ti,ab,kw OR 'chronic kidney failure':ti,ab,kw); Web of Science: ("infant, extremely low birth weight" OR elbw OR "extremely low birth weight" OR "extremely preterm" OR "extremely low birthweight") AND ("kidney function tests" OR "cystatin C" OR creatinine OR "glomerular filtration rate" OR "Renal Insufficiency, Chronic" OR "renal funct*" OR "renal complicatio*" OR "renal follow" OR "renal outcome"); ClinicalTrials.gov: (extremely low birth weight OR elbw OR extremely low birthweight OR extremely preterm) AND (kidney function test OR cystatin C OR creatinine OR glomerular filtration rate OR GFR OR chronic kidney disease OR CKD OR renal function OR renal complication OR renal follow OR renal outcome)].

Articles were screened based on title, abstract and finally full text containing information about participants (specific ELBW children, with a GFR assessment), while studies including but not reporting specific on GFR outcome in ELBW cases were not included) by the first author (EG), and uncertainties were discussed with the final author (KA) until agreement. For the full papers retained in the search, the reference list and list of citing articles were screened.

The STROBE statement checklist (Strengthening the Reporting of Observational Studies in Epidemiology) to evaluate the quality of the obtained articles and to assess the risk of bias (cohort, case-control) were used [10]. Additional quality assessment was performed, using the Newcastle-Ottawa assessment scale for case-control or cohort studies respectively [11].

From the individual papers, the following data were extracted and tabulated: study design, study size, year of birth, current age of the patient population, birth weight of the patient population, outcome parameters and results (also others than GFR), exclusion criteria, GFR measurement (including technique and/or estimation formula used) summary of reported findings and we searched if the researchers had adjusted for covariates. The mean/median GFR or eGFR values mentioned in the 
included articles were extracted to plot the GFR values over the pediatric age range. Data extraction was performed by the first author (EG), verified by the final author (KA) and differences were discussed until agreement.

\section{Results}

Following the search strategy described, $248(232+16)$ hits were analyzed to result in 6 case-control and 3 ELBW cohort studies for the analysis (Figure 1). The key characteristics of the individual case-control studies are provided in Table 1 [12-18], cohort studies in Table 2 [19-21].

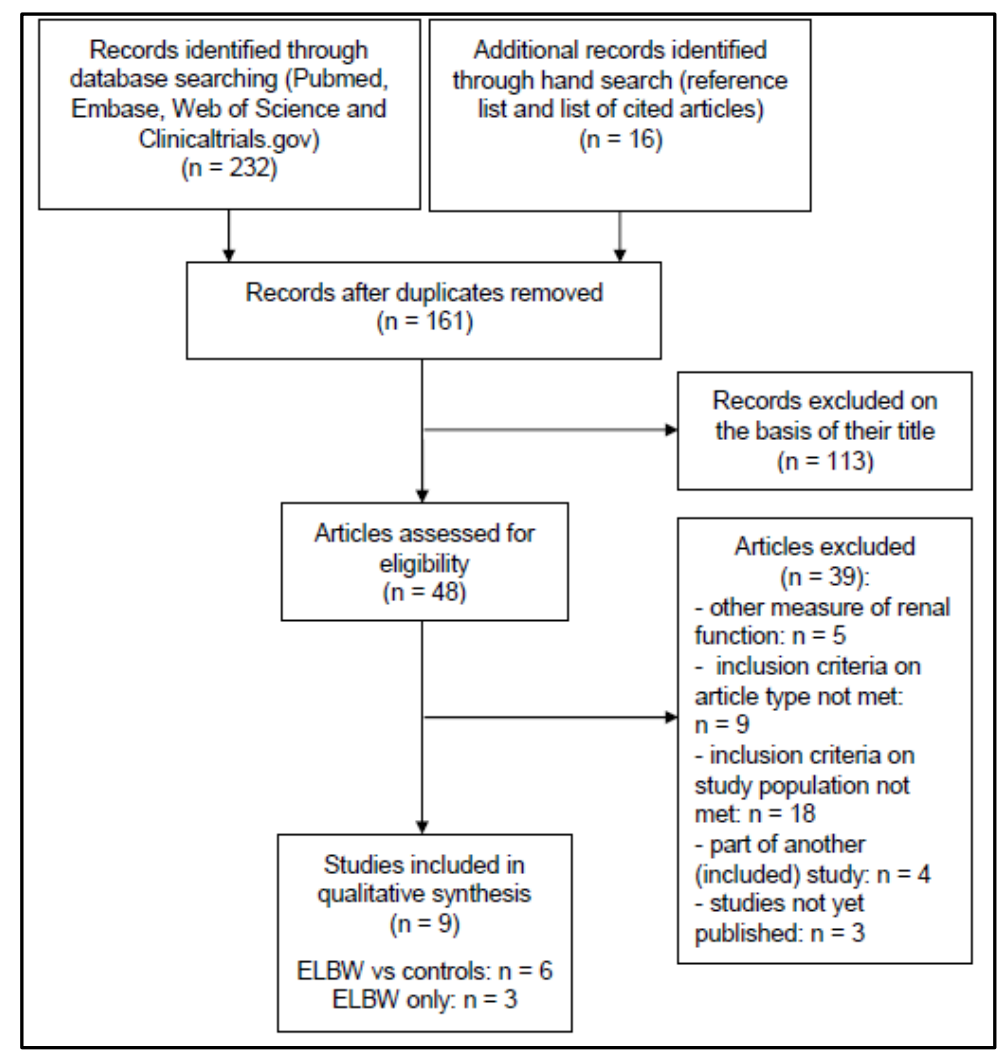

Figure 1. Preferred Reporting Items for Systematic Reviews and Meta-Analyses (PRISMA) flow chart describing the search strategy and results.

One study (Krakow cohort) collected Cys $C$ values in the same cohort at the age of 7 and 11 years and calculated eGFR values in the latest paper [14,18]. To provide an overview on the characteristics, data (eGFR data calculated) reported at the age of 7 years were added to Table 1 (italics) [18].

Table 1. Key characteristics and findings of the 6 case-control cohort studies included (chronological) [12-17].

\begin{tabular}{|c|c|c|c|c|}
\hline Study & Number, Age & Assay, Formula & Results & Comments \\
\hline $\begin{array}{l}\text { Rodriguez- } \\
\text { Soriano } 2005 \\
{[12]}\end{array}$ & $\begin{array}{l}40 \text { cases }(8.6, \\
6.1-12.4), 43 \text { controls } \\
(8.5,5.2-13) y .\end{array}$ & $\begin{array}{l}\text { modified Jaffé crea, } \\
\text { with subsequent } \\
\text { eGFR Schwartz. }\end{array}$ & $\begin{array}{l}\text { cases vs. controls: } 117(17, \text { range } \\
86-152) \text { vs. } 131(17, \text { range } 97-173) \\
\mathrm{mL} / \mathrm{min} / 1.73 \mathrm{~m}^{2}\end{array}$ & $\begin{array}{l}\text { single center, } 40 / 75 \text { ELBW cases } \\
\text { included. Controls minor } \\
\text { surgery cases. }\end{array}$ \\
\hline $\begin{array}{l}\text { Keijzer-Veen } \\
2007 \text { [13] }\end{array}$ & $\begin{array}{l}\text { 23/52 ELBW-SGA } \\
\text { cases (20.7, SD 0.3); } \\
30 \text { controls }(20.7, \text { SD } \\
0.8) \text { y. }\end{array}$ & $\begin{array}{l}\text { inulin clearance, at } \\
\text { baseline and } \\
\text { stimulated (protein } \\
\text { rich lunch + low }(2 \\
\mu \mathrm{g} / \mathrm{kg} / \mathrm{min} \text { dopa). }\end{array}$ & $\begin{array}{l}\text { cases vs. controls } \\
\text { (baseline/stimulated): } 104, \text { SD } \\
\text { 17/116, SD } 27 \text { vs. } 120, \text { SD } 28 \text { to } 141 \text {, } \\
\text { SD } 34 \mathrm{~mL} / \mathrm{min} \text {; } 107, \mathrm{SD} 15 \text { to } 119 \text {, } \\
\text { SD } 23 \mathrm{vs} .112, \mathrm{SD} 22, \text { to } 131, \mathrm{SD} 26 \\
\mathrm{~mL} / \mathrm{min} / 1.73 \mathrm{~m}^{2}\end{array}$ & $\begin{array}{l}\text { cases recruited from a } \\
\text { population follow-up study } \\
\text { former preterms (the } \\
\text { Netherlands); controls } \\
\text { volunteers. }\end{array}$ \\
\hline
\end{tabular}


Table 1. Cont.

\begin{tabular}{|c|c|c|c|c|}
\hline Study & Number, Age & Assay, Formula & Results & Comments \\
\hline $\begin{array}{l}\text { Kwinta } \\
2011 \text { [18] }\end{array}$ & $\begin{array}{l}78 \text { cases, mean age } \\
6.5 ; 38 \text { controls } \\
(6.9) \mathrm{y} .\end{array}$ & $\begin{array}{l}\text { Cys C, } \\
\text { nephelometric } \\
\text { assay (ref value } \\
4-10 \text { y } \\
0.53-0.95 \mathrm{mg} / \mathrm{L}) .\end{array}$ & $\begin{array}{l}\text { cases vs. controls }(7 \mathrm{y}) \text { : Cys C } \\
0.64(0.07) \text { vs. } 0.59(0.07) \mathrm{mg} / \mathrm{L} \text {. } \\
\text { Using the Hoek formula, equal to } \\
121 \text { vs } 131 \mathrm{~mL} / \mathrm{min} / 1.73 \mathrm{~m}^{2} \text {. }\end{array}$ & $\begin{array}{l}\text { single center, } 78 / 89 \text { cases } \\
\text { included, controls from general } \\
\text { practitioners' offices. }\end{array}$ \\
\hline $\begin{array}{l}\text { Starzec } \\
2016[14]\end{array}$ & $\begin{array}{l}64 / 78 \text { cases } \\
\text { re-studied at } 10.7 \\
36 / 38 \text { controls at } 11 \mathrm{y} \text {. }\end{array}$ & $\begin{array}{l}\text { Cys C + eGFR, } \\
\text { based on Hoek } \\
\text { formula; crea } \\
\text { (assay ?) }\end{array}$ & $\begin{array}{l}\text { cases vs. controls (11 y): Cys C } \\
0.72 \text { (SD 0.15) vs. } 0.61 \text { (SD } 0.08) \\
\mathrm{mg} / \mathrm{L} ; \text { eGFR } 107.3 \text { to } 127.4 \\
\mathrm{~mL} / \mathrm{min} / 1.73 \mathrm{~m}^{2} ; \text { crea } 43.2, \mathrm{SD} 7.7 \\
\text { vs. } 46.3, \mathrm{SD} 7.6 \mu \mathrm{mol} / \mathrm{L})\end{array}$ & $\begin{array}{l}\text { single center, } 64 / 78 \text { cases } \\
\text { retained, controls from general } \\
\text { practitioner offices. }\end{array}$ \\
\hline $\begin{array}{l}\text { Yamamura- } \\
\text { Miyazaki } \\
2017[15]\end{array}$ & $\begin{array}{l}48 \text { cases, mean age } \\
8.3 \mathrm{y} \text {, and } 48 \text { controls, } \\
8.1 \mathrm{y} .\end{array}$ & $\begin{array}{l}\text { Cys C, latex } \\
\text { turbidimetry; } \\
\text { Cys-eGFR (Uemura } \\
\text { formula); Crea } \\
\text { enzymatic; } \\
\text { Crea-eGFR } \\
\text { (assay?) }\end{array}$ & $\begin{array}{l}\text { Cases vs. controls: Cys C } 1.08 \\
\text { (0.17) vs. } 0.82(0.09) \mathrm{mg} / \mathrm{L}, \\
\text { Cys-eGFR } 90.6(15.5) \text { vs. } 120.8 \\
(14.5) \mathrm{mL} / \mathrm{min} / 1.73 \mathrm{~m}^{2} ; \text { crea } 0.46 \\
(0.09) \text { vs. } 0.37(0.08) \mathrm{mg} / \mathrm{dl} ; \\
\text { crea-eGFR } 95.4(15.5) \text { vs. } 123.9 \\
(14.5) \mathrm{mL} / \mathrm{min} / 1.73 \mathrm{~m}^{2}\end{array}$ & $\begin{array}{l}\text { single center, } 48 / 86 \text { cases } \\
\text { included; controls were } \\
\text { outpatient clinics cases. }\end{array}$ \\
\hline $\begin{array}{l}\text { Raaij-makers } \\
2017 \text { [16] }\end{array}$ & $\begin{array}{l}59 \text { cases }(11.3, \mathrm{SD} \\
1.4) ; 71 \text { controls }(10.9 \\
\text { SD } 1.3) \text { y. }\end{array}$ & $\begin{array}{l}\text { Cys C } \\
\text { (turbidimetry), } \\
\text { Cys-eGFR (CAPA } \\
\text { formula) Crea } \\
\text { (enzymatic), } \\
\text { Crea-eGFR } \\
\text { (Schwartz). }\end{array}$ & $\begin{array}{l}\text { Cases vs. controls: Cys C } 0.96 \\
\text { (0.12) vs. } 0.87(0.11) \mathrm{mg} / \mathrm{L} ; \\
\text { Cys-eGFR } 97.2(13.6) \text { vs. } 108.7 \\
(15.3) \mathrm{mL} / \mathrm{min} / 1.73 \mathrm{~m}^{2} ; \text { Crea } 0.57 \\
(0.1) \text { vs. } 0.56(0.08) \mathrm{mg} / \mathrm{dl} ; \\
\text { Crea-eGFR } 111(17) \text { vs. } 111(15) \\
\mathrm{mL} / \mathrm{min} / 1.73 \mathrm{~m}^{2} \text {. }\end{array}$ & $\begin{array}{l}\text { single center, } 93 / 140 \text { cases, but } \\
\text { blood sampling in only } 59 \text { cases. } \\
\text { Controls were volunteers. }\end{array}$ \\
\hline $\begin{array}{l}\text { Vollsaeter } \\
2018 \text { [17] }\end{array}$ & $\begin{array}{l}\text { 17 SGA cases (mean } \\
11.3) \text {, and } 45 \text { controls } \\
(11.4) \mathrm{y} \text {. }\end{array}$ & $\begin{array}{l}\text { Cys C } \\
\text { (immuno-maldi); } \\
\text { Crea } \\
\text { (chromatography); } \\
\text { eGFR Schwartz, } \\
\text { Gao (crea), } \\
\text { Zappitelli } \\
\text { (crea+Cys C) }\end{array}$ & $\begin{array}{l}\text { Cases vs. controls: Cys C } 0.91 \text { vs } \\
0.86 \mathrm{mg} / \mathrm{L} ; \text { Cys-GFR; Crea } 53.6 \text { vs. } \\
51 \mu \mathrm{mol} / \mathrm{L} ; \mathrm{GFR}_{\mathrm{Schw}} 99 \text { vs. } 110 ; \\
\text { GFR }_{\mathrm{Gao}} 98.4 \text { va } 105.6 ; \mathrm{GFR}_{\mathrm{Zapp}} \\
95.1 \text { vs. } 104.8 \mathrm{~mL} / \mathrm{min} / 1.73 \mathrm{~m}^{2} .\end{array}$ & $\begin{array}{l}\text { regional cohort with } 17 \\
\text { SGA-ELBW cases. Controls } \\
\text { volunteers from same maternity. }\end{array}$ \\
\hline
\end{tabular}

ELBW: extreme low birth weight; BUN: blood urea nitrogen; SGA: small for gestational age; eGFR: (estimated) glomerular filtration rate; Cys C: cystatin C; crea: creatinine; y: years.

Table 2 provides the same information for the 3 cohort studies retained in the analysis [19-21].

Table 2. Key characteristics of the 3 cohort studies included (chronologically) [19-21].

\begin{tabular}{|c|c|c|c|c|}
\hline Study & Number, Age & Assay, Formula & Results & Comments \\
\hline $\begin{array}{l}\text { Bacchetta } \\
2009 \text { [19] }\end{array}$ & $\begin{array}{l}50 \text { cases, } \\
7.6 \text { (range 5.8-10.3) y. }\end{array}$ & inulin clearance & $\begin{array}{l}\text { average GFR } 112 \\
\text { (range } 91-158 \mathrm{~mL} / \mathrm{min} / 1.73 \mathrm{~m}^{2} \text { ) }\end{array}$ & $\begin{array}{l}\text { single center study, 50/143 with } \\
\text { GFR in } 46 / 50 \text { cases, } \\
39 \text { ELBW cases }\end{array}$ \\
\hline $\begin{array}{l}\text { Zaffanello } \\
2010[20]\end{array}$ & $\begin{array}{l}\text { 26 ELBW cases. } 5.3 \\
(95 \% \text { CI } 5.2-6.3) \mathrm{y} .\end{array}$ & $\begin{array}{l}\text { Cys C assay } \\
\text { (nephelometry); } \\
\text { crea (modified } \\
\text { Jaffé); Schwartz } \\
\text { (crea, } \\
\text { crea/Cys-C/BUN) }\end{array}$ & $\begin{array}{l}\text { Median Cys C } 0.67 \mathrm{mg} / \mathrm{L} \text {; crea } \\
0.42 \mathrm{mg} / \mathrm{dl} ; \text { Schwartz } \\
109 \mathrm{~mL} / \mathrm{min} / 1.73 \mathrm{~m}^{2} \text {; } \\
\text { Schwartz } \\
94.5 \mathrm{~mL} / \mathrm{min} / 1.73 \mathrm{~m}^{2}\end{array}$ & $\begin{array}{l}\text { single center study, recruited } \\
69 / 97 \text { contacted cases, but } \\
1000-1500 \text { g birth weight cases } \\
\text { also recruited. }\end{array}$ \\
\hline $\begin{array}{l}\text { Matsumura } \\
2019 \text { [21] }\end{array}$ & $\begin{array}{l}43 \text { cases with } \\
\text { follow-up, } \\
7 \text { (range } 2-22 \text { ) y. }\end{array}$ & $\begin{array}{l}\text { Crea, assay } \\
\text { unknown; eGFR } \\
\text { Japanese children. }\end{array}$ & $\begin{array}{l}\text { only qualitative reporting: } \\
12(28 \%) \text { had low GFR } \\
\left(<90 \mathrm{~mL} / \mathrm{min} / 1.73 \mathrm{~m}^{2}\right)\end{array}$ & $\begin{array}{l}\text { single center, retrospective, cross } \\
\text { sectional study. }\end{array}$ \\
\hline
\end{tabular}

ELBW: extreme low birth weight; BUN: blood urea nitrogen; SGA: small for gestational age; eGFR: (estimated) glomerular filtration rate; Cys C: cystatin C; crea: creatinine; y: years.

In total, 444 GFR or eGFR measurements in 380 ELBW cases were retrieved, with an age range (median values in the different cohorts) between 5.3 and 20.7 years. The majority of studies were single center, small (17 to 78 cases), with heterogeneity in GFR measurement (inulin, cystatin C or creatinine) and estimated GFR formulae (overview supplemental Table S1) tools. Despite this, the GFR $\left(\mathrm{mL} / \mathrm{min} / 1.73 \mathrm{~m}^{2}\right)$ was consistently lower in cases (median $-13 \%$, range, $-8 \%$ to $-25 \%$ ) without significant trend over pediatric life. The median decrease $(-13 \%)$ reflects a shift of eGFR estimates of about 0.5 to $1 \mathrm{SD}$, so that a relevant minority (15-30\%) of former ELBW cases has an eGFR $<90 \mathrm{~mL} / \mathrm{min} / 1.73 \mathrm{~m}^{2}$. 
Besides the GFR values, data on other aspects of renal and general outcome (like renal ultrasound, renal tubular functions, blood pressure, biometry and body composition) were co-reported. Some papers aimed to explore perinatal risk factors like birth weight, small for gestational age (SGA), perinatal growth, Apgar score, indomethacin/ibuprofen or steroid use or gestational age, but any firm conclusion on these risk factors remained hampered by the cohort sizes.

Quality assessment based on the case-control and cohort study STROBE checklist resulted in moderate to high scores of the nine observational studies retained in the analysis. Five of the papers explicitly discussed risks of biases in the recruitment strategy $[13,15-17,20]$. In many studies, it was not entirely clear how patient selection and follow-up have been conducted. The assessment of these studies using the Newcastle-Ottawa scale (selection, comparability, outcome) also suggests moderate to high scores (Table 3).

Table 3. The Newcastle-Ottawa quality assessment scale applied to the studies retained in this analysis. Questions related to selection (Q1-4), comparability (Q5) and outcome (Q6-Q8) [11].

\begin{tabular}{|c|c|c|c|c|c|c|}
\hline $\begin{array}{l}\text { Questions Q1-Q8 } \\
\text { Case-Control }\end{array}$ & $\begin{array}{l}\text { Vollsaeter } \\
2018 \text { [17] }\end{array}$ & $\begin{array}{c}\text { Raaijmakers } \\
2017[16]\end{array}$ & $\begin{array}{c}\text { Yamamura- } \\
\text { Miyazaki } \\
2017 \text { [15] }\end{array}$ & $\begin{array}{c}\text { Starzec } 2016 \\
{[14]}\end{array}$ & $\begin{array}{c}\text { Keyzer- } \\
\text { Veen 2007 } \\
{[13]}\end{array}$ & $\begin{array}{l}\text { Rodriguez- } \\
\text { Soriano } \\
2005 \text { [12] }\end{array}$ \\
\hline case definition adequate & + & + & + & + & + & + \\
\hline representativeness cases & + & + & + & + & unknown & + \\
\hline selection controls & + & + & outpatients & outpatients & + & $\begin{array}{l}\text { minor } \\
\text { surgery }\end{array}$ \\
\hline definition controls & + & + & outpatients & outpatients & + & $\begin{array}{l}\text { minor } \\
\text { surgery }\end{array}$ \\
\hline comparability cases-controls & + & + & + & + & + & + \\
\hline ascertainment exposure & + & + & + & + & + & + \\
\hline ascertainment method & + & + & + & + & + & + \\
\hline response rate * & $+(93 \%)$ & $+(66 \%)$ & $+(55 \%)$ & $+(82 \%)$ & unknown & $+(84 \%)$ \\
\hline questions Q1-Q8 case cohort & $\begin{array}{c}\text { Matsumura } \\
2019[21]\end{array}$ & $\begin{array}{c}\text { Zaffanello } \\
2010[20]\end{array}$ & $\begin{array}{l}\text { Bachetta } \\
2009 \text { [19] }\end{array}$ & & & \\
\hline representativeness & + & + & + & & & \\
\hline selection non-exposed & n.a. & n.a. & n.a. & & & \\
\hline ascertainment exposure & + & + & + & & & \\
\hline outcome of interest presence & + & + & + & & & \\
\hline comparability & + & + & + & & & \\
\hline outcome assessment & + & + & + & & & \\
\hline follow-up, period & + & + & + & & & \\
\hline follow-up, adequacy & $+(81 \%)$ & $+(71 \%)$ & $+(35 \%)$ & & & \\
\hline
\end{tabular}

\section{Discussion}

Using a systematic review on cohort studies reporting on GFR measurements in 380 former ELBW cases throughout pediatric life, the eGFR $\left(\mathrm{mL} / \mathrm{min} / 1.73 \mathrm{~m}^{2}\right)$ was consistently lower in cases (median $-13 \%$, range, $-8 \%$ to $-25 \%$ ). The median decrease $(-13 \%)$ is similar to a shift of eGFR estimates of about 0.5 to $1 \mathrm{SD}$, so that a relevant minority (15-30\%) of former ELBW cases has an eGFR $<90 \mathrm{~mL} / \mathrm{min} / 1.73 \mathrm{~m}^{2}[16,19,21]$. We hereby confirmed the pattern of reduced GFR in former ELBW cases throughout pediatric age in line with the Brenner hypothesis $[4,5]$.

To further explore the extent of the relative difference in GFR and potential trends throughout pediatric life, we plotted the mean or median (estimated) GFR in the 6 case-control studies in Figure 2. As one of the cohorts has been assessed twice, we have added arrows to link these specific case-control GFR estimates. Based on visual inspection, the percent GFR (median $-13 \%$, range, $-8 \%$ to $-25 \%$ ) showed no clear trend of percent difference in eGFR over age between cases and controls, but this interpretation is hampered by the use of median cohort eGFR data, and not the individual eGFR data as collected. 


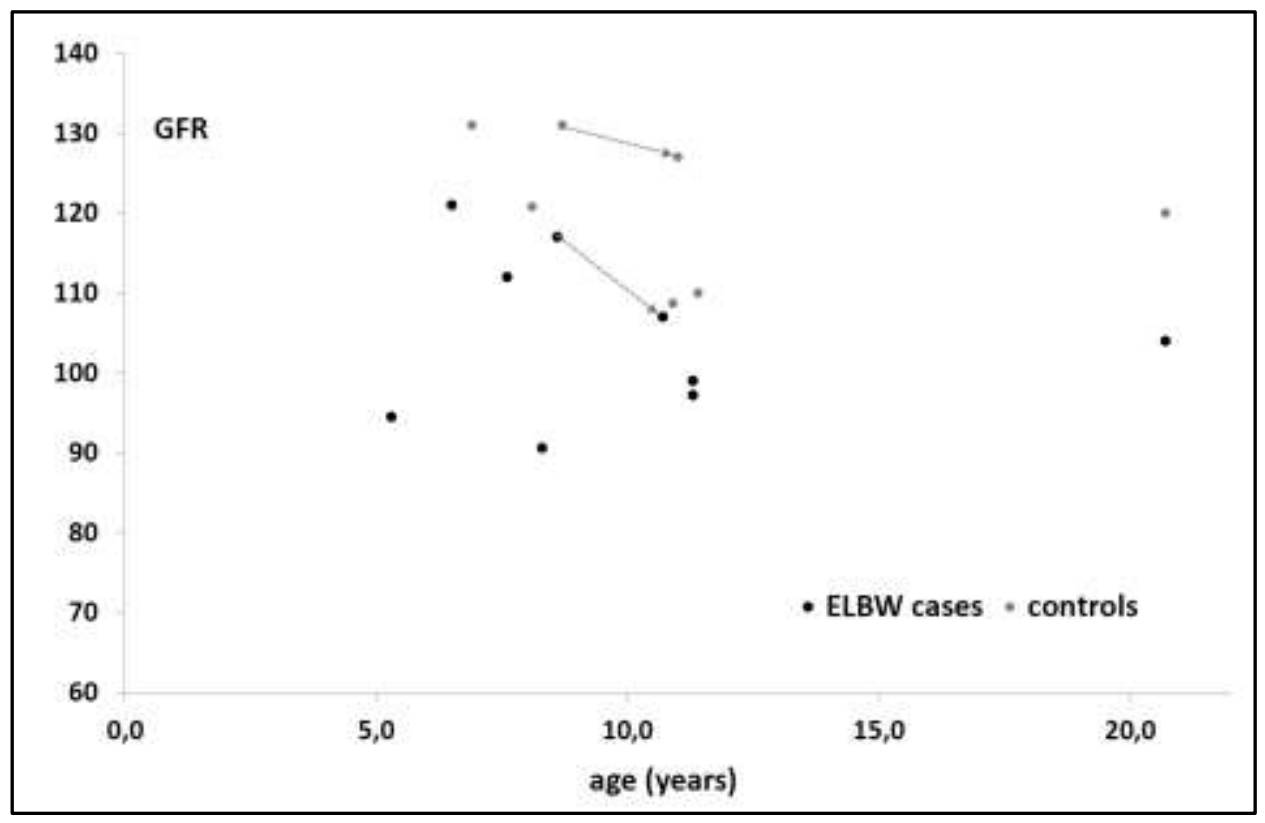

Figure 2. Mean or median (estimated) glomerular filtration rate (eGFR) in the 6 case-control studies over age (years) [12-17]. The arrows connect the same cohort assessed at the age of 7 and 11 years respectively $[17,18]$ (ELBW: extreme low birth weight).

Consequently, based on the impaired GFR outcome, clinical research should further explore the perinatal risk factors associated with this outcome and call for action to further explore the subsequent relevance of these findings beyond pediatric life. However, there are study-related issues that make such an effort difficult.

Despite the fact that the quality assessment of the studies resulted in moderate to high scores (Table 3), we still observed major relevant burdens to facilitate effective pooling. First, the source documents did not always provided sufficient information to ensure 'full' inclusions of all ELBW cases, and this may have resulted in additional overrepresentation in SGA cases if only the SGA subgroup could be included in the current pooling effort $[13,17,19]$. An obvious next step is to pool based on the individual data. Such an effort should also facilitate the exploration of the association between perinatal characteristics (like birth weight, small for gestational age (SGA), Apgar score, indomethacin/ibuprofen or steroid use or gestational age) and GFR outcome, similar to the effort recently reported to pool the ELBW renal outcome data at the age of 11 years [22]. Second and at least as relevant, such pooling effort needs to consider the heterogeneity in GFR measurement (inulin, cystatin C or creatinine estimated GFR formulae) tools and assays (cystatin C, creatinine) used [6,22].

\section{Conclusions}

Despites the study related limitations to enable pooling (small size, single center, heterogeneity GFR measurements), the pattern of reduced GFR in former ELBW cases throughout pediatric age has been confirmed. The GFR $\left(\mathrm{mL} / \mathrm{min} / 1.73 \mathrm{~m}^{2}\right)$ was consistently lower in cases (median $-13 \%$, range, $-8 \%$ to $-25 \%$ ), similar to a shift of eGFR estimates of about 0.5 to $1 \mathrm{SD}$, so that a relevant minority (15-30\%) of former ELBW cases has a eGFR $<90 \mathrm{~mL} / \mathrm{min} / 1.73 \mathrm{~m}^{2}$. Consequently, we should further explore the perinatal risk factors associated with impaired GFR outcome and the subsequent relevance of these findings beyond pediatric life.

Supplementary Materials: The following are available online at http://www.mdpi.com/1660-4601/17/6/2144/s1, Table S1: Overview of the formulae applied to calculate the estimated or inulin derived glomerular filtration rate (eGFR) in the different studies. 
Author Contributions: E.G. and K.A. jointly conceptualized this review; E.G. prepared and conducted the search strategy and performed the data extraction; K.A. cross checked and supervised the search methodology and the data extraction; D.M. and E.L. provided input during the writing and finalization of the paper and had upon-request access to the source documents. All authors have read and agreed to the submitted version of the manuscript.

Funding: This research received no external funding.

Conflicts of Interest: The authors declare no conflict of interest.

\section{References}

1. Stoll, B.J.; Hansen, N.I.; Bell, E.F.; Walsh, M.C.; Carlo, W.A.; Shankaran, S.; Laptook, A.R.; Sánchez, P.J.; Van Meurs, K.P.; Wyckoff, M.; et al. Trends in care practices, morbidity, and mortality of extremely preterm neonates, 1993-2012. JAMA 2015, 314, 1039-1051. [CrossRef] [PubMed]

2. Edstedt Bonamy, A.K.; Zeitlin, J.; Piedvache, A.; Maier, R.F.; van Heijst, A.; Varendi, H.; Manktelow, B.N.; Fenton, A.; Mazela, J.; Cuttini, M.; et al. Wide variation in severe neonatal morbidity among very preterm infants in European regions. Arch. Dis. Child. Fetal Neonatal Ed. 2019, 104, F36-F45. [CrossRef] [PubMed]

3. Faa, G.; Gerosa, C.; Fanni, D.; Monga, G.; Zaffanello, M.; Van Eyken, P.; Fanos, V. Morphogenesis and molecular mechanisms involved in human kidney development. J. Cell. Physiol. 2012, 227, 1257-1268. [CrossRef] [PubMed]

4. Low Birth Weight and Nephron Number Working Group. The impact of kidney development on the life course: A consensus document for action. Nephron 2017, 136, 3-49. [CrossRef] [PubMed]

5. Luyckx, V.A.; Perico, N.; Somaschini, M.; Manfellotto, D.; Valensise, H.; Cetin, I.; Simeoni, U.; Allegaert, K.; Vikse, B.E.; Steegers, E.A.; et al. A developmental approach to the prevention of hypertension and kidney disease: A report from the Low Birth Weight and Nephron Number Working Group. Lancet 2017, 390, 424-428. [CrossRef]

6. Farrance, I.; Badrick, T.; Frenkel, R. Uncertainty in measurement: A review of the procedures for determining uncertainty in measurement and its use in deriving the biological variation of the estimated glomerular filtration rate. Pract. Lab. Med. 2018, 12, e00097. [CrossRef] [PubMed]

7. Murata, K.; Baumann, N.A.; Saenger, A.K.; Larson, T.S.; Rule, A.D.; Lieske, J.C. Relative performance of the MDRD and CKD-EPI equations for estimating glomerular filtration rate among patients with varied clinical presentations. Clin. J. Am. Soc. Nephrol. 2011, 6, 1963-1972. [CrossRef]

8. Björk, J.; Nyman, U.; Berg, U.; Delanaye, P.; Dubourg, L.; Goffin, K.; Grubb, A.; Hansson, M.; Littmann, K.; Åsling-Monemi, K.; et al. Validation of standardized creatinine and cystatin C GFR estimating equations in a large multicenter European cohort of children. Pediatr. Nephrol. 2019, 34, 1087-1098. [CrossRef]

9. Shamseer, L.; Moher, D.; Clarke, M.; Ghersi, D.; Liberati, A.; Petticrew, M.; Shekelle, P.; Stewart, L.A.; PRISMA-P Group. Preferred reporting items for systematic review and meta-analysis protocols (PRISMA-P) 2015: Elaboration and explanation. BMJ 2015, 349, g7647. [CrossRef]

10. von Elm, E.; Altman, D.G.; Egger, M.; Pocock, S.J.; Gøtzsche, P.C.; Vandenbroucke, J.P.; STROBE Initiative. The strengthening the reporting of observational studies in epidemiology (STROBE) statement: Guidelines for reporting observational studies. Int. J. Surg. 2014, 12, 1495-1499. [CrossRef]

11. Zeng, X.; Zhang, Y.; Kwong, J.S.; Zhang, C.; Li, S.; Sun, F.; Niu, Y.; Du, L. The methodological quality assessment tools for preclinical and clinical studies, systematic review and meta-analysis, and clinical practice guideline: A systematic review. J. Evid. Based Med. 2015, 8, 2-10. [CrossRef] [PubMed]

12. Rodriguez-Soriano, J.; Aguirre, M.; Oliveros, R.; Vallo, A. Long-term renal follow-up of extremely low birth weight infants. Pediatr. Nephrol. 2005, 20, 579-584. [CrossRef] [PubMed]

13. Keijzer-Veen, M.G.; Schrevel, M.; Finken, M.J.; Dekker, F.W.; Nauta, J.; Hille, E.T.; Frölich, M.; van der Heijden, B.J.; Dutch POPS-19 Collaborative Study Group. Microalbuminuria and lower glomerular filtration rate at young adult age in subjects born very premature and after intrauterine growth retardation. J. Am. Soc. Nephrol. 2005, 16, 2762-2768.

14. Starzec, K.; Klimek, M.; Grudzień, A.; Jagla, M.; Kwinta, P. Longitudinal assessment of renal size and function in extremely low birth weight children at 7 and 11 years of age. Pediatr. Nephrol. 2016, 31, 2119-2126. [CrossRef] 
15. Yamamura-Miyazaki, N.; Yamamoto, K.; Fujiwara, K.; Santo, Y.; Michigami, T.; Kitajima, H.; Satomura, K. Risk factors associated with a decreased estimated glomerular filtration rate based on cystatin C levels in school-age children with extremely low birthweight. Nephrology 2017, 22, 463-469. [CrossRef]

16. Raaijmakers, A.; Zhang, Z.Y.; Claessens, J.; Cauwenberghs, N.; van Tienoven, T.P.; Wei, F.F.; Jacobs, L.; Levtchenko, E.; Pauwels, S.; Kuznetsova, T.; et al. Does extremely low birth weight predispose to low-renin hypertension? Hypertension 2017, 69, 443-449. [CrossRef]

17. Vollsæter, M.; Halvorsen, T.; Markestad, T.; Øymar, K.; Ueland, P.M.; Meyer, K.; Midttun, Ø.; Bjørke-Monsen, A.L. Renal function and blood pressure in 11 year old children born extremely preterm or small for gestational age. PLoS ONE 2018, 13, e0205558. [CrossRef]

18. Kwinta, P.; Klimek, M.; Drozdz, D.; Grudzień, A.; Jagla, M.; Zasada, M.; Pietrzyk, J.J. Assessment of long-term renal complications in extremely low birth weight children. Pediatr. Nephrol. 2011, 26, 1095-1103. [CrossRef]

19. Bacchetta, J.; Harambat, J.; Dubourg, L.; Guy, B.; Liutkus, A.; Canterino, I.; Kassaï, B.; Putet, G.; Cochat, P. Both extrauterine and intrauterine growth restriction impair renal function in children born very preterm. Kidney Int. 2009, 76, 445-452. [CrossRef]

20. Zaffanello, M.; Brugnara, M.; Bruno, C.; Franchi, B.; Talamini, G.; Guidi, G.; Cataldi, L.; Biban, P.; Mella, R.; Fanos, V. Renal function and volume of infants born with a very low birth-weight: A preliminary cross-sectional study. Acta Paediatr. 2010, 99, 1192-1198.

21. Matsumura, K.; Matsuzaki, Y.; Hida, M.; Ikeda, K.; Awazu, M. Tubular dysfunction in extremely low birth weight survivors. Clin. Exp. Nephrol. 2019, 23, 395-401. [CrossRef] [PubMed]

22. Gilarska, M.; Raaijmakers, A.; Zhang, Z.Y.; Staessen, J.A.; Levtchenko, E.; Klimek, M.; Grudzień, A.; Starzec, K.; Allegaert, K.; Kwinta, P. Extremely low birth weight predisposes to impaired renal health: A pooled analysis. Kidney Blood Press. Res. 2019, 44, 897-906. [CrossRef] [PubMed]

(C) 2020 by the authors. Licensee MDPI, Basel, Switzerland. This article is an open access article distributed under the terms and conditions of the Creative Commons Attribution (CC BY) license (http://creativecommons.org/licenses/by/4.0/). 